\title{
Mixotrophic Capabilities of Alcaligenes eutrophus
}

\author{
By UWE KÄRST AND CORNELIUS G. FRIEDRICH* \\ Institute für Mikrobiologie der Universität Göttingen, Grisebachstrasse 8, D-3400 Göttingen, \\ Federal Republic of Germany
}

(Received 30 January 1984 ; revised 12 March 1984)

The facultatively chemolithoautotrophic hydrogen bacterium Alcaligenes eutrophus was able to utilize organic and inorganic substrates concomitantly, i.e. to grow mixotrophically. The mixotrophic capabilities were investigated under succinate-limited growth of $A$. eutrophus with molecular hydrogen in a gas atmosphere devoid of carbon dioxide. At a dilution rate $(D)$ of $0.2 \mathrm{~h}^{-1}$, the mixotrophic cellular yield was increased by $135 \%$ over the heterotrophic yield with succinate alone. Total carbon analysis revealed that under these conditions $95 \%$ of the succinate carbon was converted to cell carbon. The mixotrophic yield decreased only slightly at dilution rates lower than $0.2 \mathrm{~h}^{-1}$ but significantly at higher dilution rates and was only $18 \%$ above the heterotrophic yield at $D=0.32 \mathrm{~h}^{-1}$. Unlike other facultative chemoautotrophs, mixotrophic growth of $A$. eutrophus required both $\mathrm{H}_{2}$ oxidation (Hox) and autotrophic $\mathrm{CO}_{2}$ fixation (Cfx), as evident from mutants defective in either $\mathrm{H}_{2}$ oxidation $\left(\mathrm{Hox}^{-}\right)$or autotrophic metabolism $\left(\mathrm{Cfx}^{-}\right)$, as well as from incorporation studies of radioactive substrates. The cellular yield of a $\mathrm{Cf} \mathrm{x}^{-}$mutant, $\mathrm{HF} 17$, increased only slightly (by $14 \%$ ) upon the addition of $\mathrm{H}_{2}$, indicating that the ability of $A$. eutrophus to change the metabolism of a heterotrophic substrate was limited. Hox $^{-}$mutants did not increase their cellular yield under identical growth conditions.

\section{INTRODUCTION}

Among the aerobic chemolithoautotrophic bacteria only the $\mathrm{H}_{2}$-oxidizing bacteria are generally facultative chemolithoautotrophs. These bacteria grow on a variety of organic compounds as carbon and energy source, as well as with $\mathrm{H}_{2}$ as electron donor and $\mathrm{CO}_{2}$ as carbon source.

$\mathrm{H}_{2}$ is activated by hydrogenases and $\mathrm{CO}_{2}$ is assimilated autotrophically via the Calvin cycle with the initial reactions of phosphoribulokinase and ribulose-1,5-bisphosphate carboxylase (RuBPCase). The majority of the so-called thiobacilli are obligate chemolithoautotrophs (Rittenberg, 1969). However, the nitrifying bacteria have been reported to utilize organic substrates (Steinmüller \& Bock, 1976). The concomitant utilization of organic and inorganic substrates as carbon and energy sources has been designated as mixotrophy. This type of metabolism is probably of major ecological significance for the facultative chemolithotrophic bacteria since both substrates are present in their natural environment.

Mixotrophic growth is judged from the increase in cellular yield as compared to growth on one substrate alone. This can be achieved by two different metabolic routes. First, the chemolithotrophic metabolism, rather than the dissimilation of a carbon source, is used to satisfy the energy needs of the bacterium and the carbon source is assimilated instead. Secondly, mixotrophy involves autotrophic $\mathrm{CO}_{2}$ fixation for which the inorganic electron donor supplies the necessary energy, while the heterotrophic metabolism of the organic substrate remains largely unchanged.

Mixotrophy has been observed in a number of hydrogen bacteria and some thiobacilli, as reviewed by Bowien \& Schlegel (1981) and Matin (1978). For Thiobacillus A2, the carbon 
monoxide oxidizing bacterium Pseudomonas carboxydoflava, and the hydrogen bacterium Aquaspirillum autotrophicum (Fasnacht \& Aragno, 1982) evidence was presented that mixotrophy does not involve autotrophic $\mathrm{CO}_{2}$ fixation (Smith et al., 1980; Kiessling \& Meyer, 1982).

Mixotrophic growth has been reported for Alcaligenes eutrophus when pre-cultivated under autotrophic growth conditions (Rittenberg \& Goodman, 1969). However, when cells were precultivated on a heterotrophic substrate like pyruvate, a biphasic growth was observed (Stukus \& DeCicco, 1970) suggesting subsequent autotrophic growth. With pyruvate the formation of the key enzymes of autotrophic metabolism is repressed in $A$. eutrophus (Stukus \& DeCicco, 1970; Friedrich et al., 1981). However, their formation is derepressed during carbon-limited heterotrophic growth in a chemostat (Friedrich, 1982). We therefore used the continuous-culture technique to quantify the mixotrophic capabilities of $A$. eutrophus. We used radioactive substrates and mutants defective in either $\mathrm{H}_{2}$ oxidation or autotrophic $\mathrm{CO}_{2}$ fixation to determine the involvement of the Calvin cycle in the mixotrophy in this strain. Here we report that $A$. eutrophus dissimilates the organic carbon source under mixotrophic growth conditions in the same way as it does during heterotrophic growth. With $\mathrm{H}_{2}$ as additional energy source, the $\mathrm{CO}_{2}$ derived from the dissimilation is completely refixed via the Calvin cycle.

\section{METHODS}

Bacterial strains. Alcaligenes eutrophus strain H16 (ATCC 17699; DSM 428) and mutants deficient in hydrogenase activity (Friedrich et al., 1982) or deficient in autotrophic $\mathrm{CO}_{2}$ fixation (Friedrich et al., 1979) were used.

Media and growth conditions. The media for seed cultures and continuous cultivation were identical to those described by Friedrich (1982), with the exception that the concentration of succinic acid was $2.0 \mathrm{~g} \mathrm{I}^{-1}$ and antifoam was used (polypropylene glycol, $50 \mathrm{mg} \mathrm{l}^{-1}$ ). For heterotrophic and mixotrophic growth a 21 fermenter (B. Braun, Melsungen, FRG) with $\mathrm{pH}$ control was used as previously described (Friedrich, 1982). For heterotrophic growth the culture was aerated $\left(300 \mathrm{ml} \mathrm{min}^{-1}\right)$ by precision piston pumps with artificial air $\left[\mathrm{N}_{2} / \mathrm{O}_{2}\right.$ $(80: 20, \mathrm{v} / \mathrm{v})]$ devoid of $\mathrm{CO}_{2}$. Mixotrophic growth conditions were given by a gas atmosphere of $\mathrm{N}_{2} / \mathrm{O}_{2} / \mathrm{H}_{2}$ $\left(60: 20: 20\right.$, by vol.). The dilution rate was $0.05 \mathrm{~h}^{-1}$ unless otherwise stated.

The steady state of a culture had been reached when $\mathrm{OD}_{436}$ and the enzyme activities remained constant with time. This required usually three to five volume changes. The strain characteristics of the mutants were examined frequently and found to be constant throughout the duration of the continuous culture.

Dry cell weight and total carbon analysis. Dry cell weight was determined by filtration of $10 \mathrm{ml}$ of medium; cells were washed once with $0.9 \%(\mathrm{w} / \mathrm{v}) \mathrm{NaCl}$ and dried overnight at $90{ }^{\circ} \mathrm{C}$. Total organic carbon was determined from culture fluids, supernatants and samples of washed cell suspensions. Organic carbon was oxidized to $\mathrm{CO}_{2}$ and quantified by an infrared analyser, model 915-B (Beckman Instruments).

Radioactive tracer studies. Cells were grown in batch cultures $(20 \mathrm{ml})$ with isoleucine $(0 \cdot 1 \%, \mathrm{w} / \mathrm{v})$ under an atmosphere of artificial air $\left[\mathrm{N}_{2} / \mathrm{O}_{2}(80: 20, \mathrm{v} / \mathrm{v})\right]$ or where $\mathrm{N}_{2}$ was replaced by $\mathrm{H}_{2}$. At early exponential growth phase $1 \mu \mathrm{Ci}(37 \mathrm{kBq}) \mathrm{L}-\left[\mathrm{U}-{ }^{14} \mathrm{C}\right]$ isoleucine was added and the incorporation of radioactive carbon into the cells was followed. Samples $(1 \mathrm{ml})$ were acidified with $0.1 \mathrm{ml} 3.3 \mathrm{M}-\mathrm{H}_{3} \mathrm{PO}_{4}$, washed once with $1 \mathrm{M}-\mathrm{H}_{3} \mathrm{PO}_{4}$, resuspended in $50 \mathrm{mM}$-potassium phosphate buffer $\mathrm{pH} \mathrm{7.0}$ and the radioactivity of a sample was determined.

Enzyme assays. Enzyme activities were measured at $30^{\circ} \mathrm{C}$. Soluble hydrogenase (EC 1.12.1.2) either from whole cells or cell-free extracts was determined by spectrophotometric analysis of NADH as previously described (Friedrich et al., 1982). Membrane-bound hydrogenase was determined from washed membranes as described by Friedrich et al. (1979). RuBPCase (EC 4.1.1.39) was determined from whole cells according to Leadbeater $e$ al . (1982). One unit (U) of enzyme activity is defined as $1 \mu \mathrm{mol}$ substrate transformed or product formed $\mathrm{min}^{-1}$. Protein was determined by the Lowry method.

Chemicals. NAD was purchased from Boehringer. Antifoam P-2000 was from Fluka AG (Buchs, Switzerland). Ribulose-1,5-bisphosphate was obtained from G. Whitesides, Harvard University (Cambridge, Mass., USA). $\mathrm{L} \cdot\left[\mathrm{U}-{ }^{14} \mathrm{C}\right\}$ Isoleucine was purchased from Amersham Buchler (Braunschweig, FRG). All gases were of purissime grade and from Messer Griesheim (Kassel, FRG). Other chemicals were of analytical grade and purchased from Merck.

\section{RESULTS}

Yield studies

For determination of the cellular yields $\left(Y_{\mathrm{s}}\right)$ A. eutrophus strain $\mathrm{H} 16$ and mutants defective in autotrophic or chemolithotrophic metabolism were grown in a succinate-limited chemostat at a 

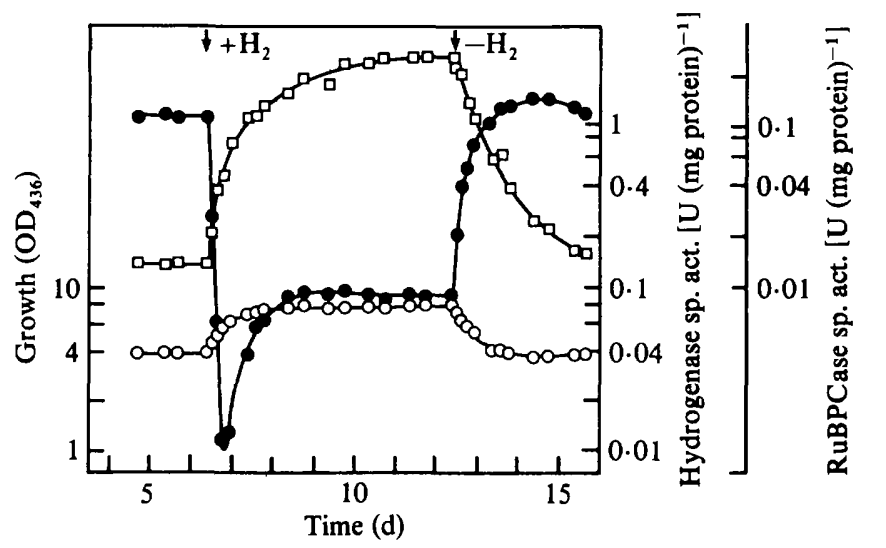

Fig. 1. Cell mass and enzyme activities of $A$. eutrophus during transition from heterotrophic to mixotrophic growth in a succinate-limited chemostat. The culture conditions and gas atmospheres were as described in Methods. The dilution rate was $0.05 \mathrm{~h}^{-1}$. Arrows indicate the addition or removal of $20 \%(\mathrm{v} / \mathrm{v}) \mathrm{H}_{2}$ to the gas atmosphere; the changes in gas composition were compensated with $\mathrm{N}_{2}$. $\bigcirc$, Optical density at $436 \mathrm{~nm}$; $O$, specific activity of soluble hydrogenase; $\square$, specific activity of RuBPCase.

\title{
Table 1. Yields of Alcaligenes eutrophus during succinate-limited heterotrophic and mixotrophic growth in a chemostat
}

\begin{abstract}
The yields were determined from at least five samples withdrawn at various times during the steady state, all giving identical results. Mixotrophic growth conditions were produced in the succinate-limited chemostats by the addition of $20 \%(\mathrm{v} / \mathrm{v}) \mathrm{H}_{2}$ to the gas phase.
\end{abstract}

\begin{tabular}{|c|c|c|c|c|}
\hline \multirow[b]{2}{*}{ Strain } & \multirow[b]{2}{*}{$\begin{array}{l}\text { Relevant } \\
\text { phenotype }\end{array}$} & \multirow[b]{2}{*}{$\underset{\left(\mathrm{h}^{-1}\right)}{D}$} & \multicolumn{2}{|c|}{$\begin{array}{c}\text { Cellular yield } \\
\left.[\mathrm{g} \text { dry wt (g succinic acid })^{-1}\right]\end{array}$} \\
\hline & & & $\overbrace{-\mathrm{H}_{2}}$ & $+\mathrm{H}_{2}$ \\
\hline H16 & Hox ${ }^{+*}$ & 0.050 & $0 \cdot 35$ & 0.70 \\
\hline HF08 & Hop $^{-\dagger}$ & 0.051 & $0 \cdot 33$ & 0.70 \\
\hline HF 14 & Hos $^{-} \ddagger$ & 0.053 & 0.34 & 0.71 \\
\hline HF 18 & Hox $^{-}$ & 0.055 & 0.36 & 0.35 \\
\hline HF 17 & $C f x-\S$ & 0.050 & 0.35 & 0.40 \\
\hline
\end{tabular}

* Ability to oxidize $\mathrm{H}_{2}$.

† Inability to form particulate hydrogenase activity.

$\ddagger$ Inability to form soluble hydrogenase activity.

$\S$ Inability to fix $\mathrm{CO}_{2}$ via the Calvin cycle.

dilution rate $(D)$ of about $0.05 \mathrm{~h}^{-1}$. During steady state the cellular yield of the wild-type strain $\mathrm{H} 16$ was $0.35 \mathrm{~g}$ dry wt (g succinic acid) ${ }^{-1}$.

When mixotrophic growth conditions were produced by the addition of $20 \%(\mathrm{v} / \mathrm{v}) \mathrm{H}_{2}$ to the gas phase, the $Y_{\mathrm{s}}$ increased by $100 \%$ to $0.70 \mathrm{~g}$ dry wt (g succinic acid) ${ }^{-1}$ (Table 1). Identical yields during heterotrophic and mixotrophic growth were observed with mutant strain HF08, deficient in the particulate hydrogenase $\left(\mathrm{Hop}^{-}\right)$, or strain $\mathrm{HF} 14$, deficient in the soluble hydrogenase $\left(\mathrm{Hos}^{-}\right.$) activity. As expected, the yield of strain HF18, unable to oxidase $\mathrm{H}_{2}$, was identical under heterotrophic and mixotrophic growth conditions. A slight but distinct yield increase of $14 \%$ was observed with strain $\mathrm{HF} 17$, unable to fix $\mathrm{CO}_{2}$ via the Calvin cycle (Table 1 ). The protein content of the strains investigated was identical during heterotrophic or mixotrophic growth and was about $0.7 \mathrm{~g}$ protein (g dry wt) ${ }^{-1}$.

To correlate the cellular yields with the yield of the assimilated carbon $\left(Y_{c}\right)$ the total organic carbon of washed cells was determined. The elemental analysis of the wild type and mutants revealed that the carbon content was about $47 \%$ of the dry cell weight from cells grown either 
heterotrophically or mixotrophically. The $Y_{c}$ values paralleled those obtained for the cellular yield $Y_{\mathrm{s}}$ (data not shown). Besides the yields the growth characteristics during transition from heterotrophic to mixotrophic steady state were determined. Upon the addition of hydrogen to the chemostat the cell concentration of strain $\mathrm{H} 16$ increased exponentially with a transitional growth rate $\left(\mu_{\mathrm{t}}\right)$ of $0.047 \mathrm{~h}^{-1}$ (Fig. 1). During steady state in a chemostat the dilution rate, $D$, is equivalent to the specific growth rate, $\mu$. Therefore, during transition from heterotrophic to mixotrophic steady state the overall growth rate $(\mu)$ is given by the dilution rate and the transitional growth rate $\mu_{1}$ (equation 1):

$$
\mu=D+\mu_{\mathrm{t}}
$$

Since for strain $\mathrm{H} 16$ the dilution rate was $0.050 \mathrm{~h}^{-1}$ (Table 1), the overall growth rate was $0.097 \mathrm{~h}^{-1}$. An identical growth rate $\left(0.098 \mathrm{~h}^{-1}\right)$ was determined with strain HF08 (Hop $\left.{ }^{-}\right)$. However, with strain HF14, lacking the soluble hydrogenase activity, a substantially lower rate of $0.074 \mathrm{~h}^{-1}$ was observed. Strain HF17 $\left(\mathrm{Cfx}^{-}\right)$grew with an overall rate of $0.058 \mathrm{~h}^{-1}$.

\section{Mixotrophic enzyme activities}

The above results suggested the involvement of autotrophic $\mathrm{CO}_{2}$ fixation as well as $\mathrm{H}_{2}$ oxidation during mixotrophy. Therefore, the activities of the key enzymes of autotrophic metabolism were determined from cells grown under both conditions.

During succinate-limited heterotrophic growth at a dilution rate of $0.05 \mathrm{~h}^{-1}$ A. eutrophus formed both the soluble and the particulate hydrogenase at highly derepressed activities of 1.09 and $0.35 \mathrm{U}$ (mg protein) ${ }^{-1}$, respectively. RuBPCase activity was low [0.014 U (mg protein) $)^{-1}$ ] (Table 2). These results confirmed those of Friedrich (1982). Upon the addition of $\mathrm{H}_{2}$ the activity of the soluble hydrogenase decreased dramatically with first order kinetics and a half life of $1.5 \mathrm{~h}$ (Fig. 1) in the wild type and similarly in the Hop ${ }^{-}$strain HF08 and the Cfx ${ }^{-}$strain HF17. The drop in activity was due to in vivo inactivation, as described by Schlesier \& Friedrich (1981). The activity of the particulate hydrogenase remained high under both growth conditions in the parent and in the mutant strains able to form particulate hydrogenase.

A 20-fold increase in RuPBCase activity during mixotrophic growth was observed in the wild type (Fig. 1), and the Hop ${ }^{-}$and $\mathrm{Hos}^{-}$strains HF08 and HF14, respectively (Table 2). In these strains RuBPCase was formed in about tenfold excess over the catalytic needs of $\mathrm{CO}_{2}$-fixing activity ( $\mathrm{Cfa}$ ) of the $\mathrm{CO}_{2}$ derived from succinate. This was calculated according to equation (2):

$$
\mathrm{Cfa}=\frac{D / 60 \mu \mathrm{mol} \mathrm{C} \mathrm{l}^{-1}}{\mathrm{mg} \text { protein } \mathrm{I}^{-1}}
$$

In the Hox ${ }^{-}$strain HF18, RuBPCase activity remained low during mixotrophic growth.

\section{Radioactive labelling studies}

The inability of the $\mathrm{Cf} \mathrm{X}^{-}$mutant HF17 to increase the yield equivalent to the parent under mixotrophic growth conditions with succinate plus $\mathrm{H}_{2}$ strongly suggested the involvement of autotrophic $\mathrm{CO}_{2}$ fixation in mixotrophy in the parent. This line of evidence was further investigated. With succinate, $A$. eutrophus does not form the key enzymes of autotrophic metabolism in batch culture, while these enzymes are well expressed with isoleucine as carbon and energy source (Friedrich \& Friedrich, 1983). Therefore, uniformly labelled $\left[{ }^{14} \mathrm{C}\right]$ isoleucine was used to determine the amount of carbon incorporated into cell mass (as described in Methods). During heterotrophic growth, about $35 \%$ of the initial radioactive carbon was incorporated by the wild type but $67 \%$ was incorporated under mixotrophic conditions with $\mathrm{H}_{2}$. The addition of $3 \mathrm{~mm}$ unlabelled bicarbonate decreased the incorporation of the radioactivity to $48 \%$ during mixotrophy. Strain HF17 $\left(\mathrm{Cfx}^{-}\right)$did not increase the yield or incorporation of radioactive carbon with isoleucine under mixotrophic growth conditions in batch culture (data not shown). 
Table 2. Enzyme activities of autotrophic metabolism during succinate-limited heterotrophic and mixotrophic growth of $A$. eutrophus in a chemostat

The growth conditions with respect to substrate concentration, gas atmosphere, and dilution rate were identical to those of Table 1. Hydrogenase activities were determined in extracts as described in Methods.

\begin{tabular}{|c|c|c|c|c|c|c|c|}
\hline \multirow[b]{4}{*}{ Strain } & & \multicolumn{6}{|c|}{ Specific activity $\left[\mathrm{U}(\mathrm{mg} \text { protein })^{-1}\right]$} \\
\hline & \multirow{3}{*}{$\begin{array}{c}\text { Relevant } \\
\text { phenotype }\end{array}$} & \multicolumn{4}{|c|}{ Hydrogenase } & & \\
\hline & & \multicolumn{2}{|c|}{ Soluble } & \multicolumn{2}{|c|}{ Particulate } & \multicolumn{2}{|c|}{ RuBPCase } \\
\hline & & $-\mathrm{H}_{2}$ & $+\mathrm{H}_{2}$ & $-\mathrm{H}_{2}$ & $+\mathrm{H}_{2}$ & $-\mathrm{H}_{2}$ & $+\mathrm{H}_{2}$ \\
\hline H16 & Hox $^{+}$ & 1.09 & 0.09 & 0.35 & 0.33 & 0.014 & 0.254 \\
\hline HF08 & Hop ${ }^{-}$ & 1.49 & $0 \cdot 15$ & 0 & 0 & 0.012 & 0.237 \\
\hline HF14 & $\operatorname{Hos}^{-}$ & 0 & 0 & 0.59 & 0.53 & 0.014 & 0.261 \\
\hline HF18 & Hox - & 0 & 0 & 0 & 0 & 0.005 & 0.004 \\
\hline HF 17 & $\mathrm{Cfx}^{-}$ & $1 \cdot 35$ & 0 & 0.35 & 0.35 & 0 & 0 \\
\hline
\end{tabular}

* The phenotype designation is given in the text and Table 1.

\section{Growth rate dependent mixotrophic metabolism}

The yield increase during mixotrophy is determined by the rate of substrate conversion in autotrophic metabolism. This rate depends on two factors: (i) the activities of the enzymes involved, and (ii) the availability of the autotrophic substrates. The mixotrophic capability of A. eutrophus was determined by changing the dilution rate in a chemostat. The activities of the key enzymes of autotrophic metabolism as well as the yields were determined from the various steady states.

During heterotrophic growth under succinate limitation the concentration of cell mass $(X)$ of A. eutrophus was about $0.7 \mathrm{~d}$ dry wt $1^{-1}$ at a dilution rate of $0.065 \mathrm{~h}^{-1}$, increasing slightly to $0.73 \mathrm{gdry} \mathrm{wt}^{-1}$ at $D=0.4 \mathrm{~h}^{-1}$ (Fig. $2 a$ ). Consequently the productivity $(P)$ of the culture given by the product of the cell concentration, $X$, and the dilution rate, $D$ (see equation 3 ), increased linearly with increasing dilution rate (Fig. $2 b$ ).

$$
P\left(\frac{\mathrm{gdry} w \mathrm{t}}{1 . \mathrm{h}}\right)=X\left(\frac{\mathrm{g} \text { dry wt }}{1}\right) \cdot D\left(\mathrm{~h}^{-1}\right)
$$

Under succinate-limited mixotrophic growth with $\mathrm{H}_{2}$ in the gas atmosphere the cell concentration increased by $100 \%$ to $1.4 \mathrm{~g}$ dry wt $\mathrm{l}^{-1}$ at a dilution rate of $0.048 \mathrm{~h}^{-1}$ (Fig. 2). This was equivalent to a cellular yield of $0.7 \mathrm{~g}$ dry wt (g succinic acid) ${ }^{-1}$ (Table 1 ). When the dilution

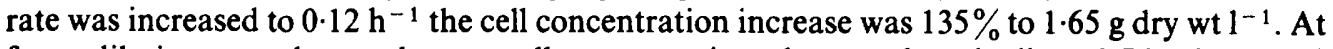
faster dilution rates the steady state cell concentrations decreased gradually to $0.76 \mathrm{~g}$ dry wt $\mathrm{I}^{-1}$ at a dilution rate of $0.4 \mathrm{~h}^{-1}$.

The fraction of the autotrophic metabolism contributing to mixotrophic growth at the various dilution rates can be deduced from these data by the differences in cell concentration $(X)$ or the productivities $(P)$ of mixotrophic and heterotrophic growth (Fig. $2 a, b$; broken line) according to equation (4):

$$
P_{\text {autotrophic }}=P_{\text {mixotrophic }}-P_{\text {heterotrophic }}
$$

Under the given growth conditions with $2 \mathrm{~g}$ succinic acid $1^{-1}$ in the feed medium, the productivity of the autotrophic metabolism exhibited a maximum of about $0.15 \mathrm{~g} \mathrm{dry} \mathrm{wt}^{-1} \mathrm{~h}^{-1}$ at a dilution rate of $0.155 \mathrm{~h}^{-1}$ (Fig. $2 \mathrm{~b}$ ). At this and lower dilution rates the autotrophic metabolism contributed up to $66 \%$ of the overall mixotrophic yield and consequently its productivity. Above $D=0.2 \mathrm{~h}^{-1}$ the fraction of the autotrophic metabolism declined but was still $18 \%$ of the total productivity at $D=0.32 \mathrm{~h}^{-1}$. 


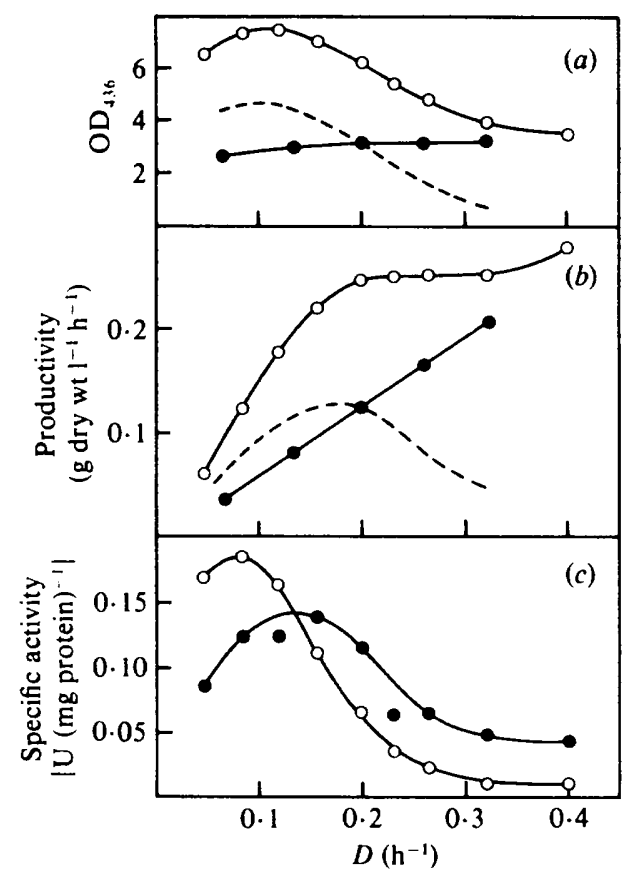

Fig. 2. Heterotrophic and mixotrophic cellular growth, productivities and enzyme activities of $\boldsymbol{A}$. eutrophus grown in a succinate-limited chemostat. The culture conditions and gas atmospheres were as described in Methods. (a) Optical density of mixotrophic (O) and heterotrophic growth $(O) ;(b)$ productivity of mixotrophic $(O)$ and heterotrophic $(O)$ growth; $(c)$ specific activities of RuBPCase $(O)$. and soluble hydrogenase $(O)$ under mixotrophic growth conditions. The broken lines indicate the difference between mixotrophic and heterotrophic growth $(a)$ and productivity $(b)$.

To estimate whether or not the activities of the key enzymes of autotrophic metabolism caused the restriction in yield and productivity during mixotrophic growth at the higher dilution rates, the specific activities of soluble hydrogenase and RuBPCase were determined. The maximum specific activity of soluble hydrogenase during mixotrophic growth was $0 \cdot 18 \mathrm{U}(\mathrm{mg}$ protein $)^{-1}$ at a dilution rate of $0.085 \mathrm{~h}^{-1}$ (Fig. $2 c$ ). At this dilution rate the hydrogenase activity was only 10 to $20 \%$ of that found during heterotrophic growth. At higher dilution rates the specific activity declined drastically and was hardly detectable above $D=0.3 \mathrm{~h}^{-1}$. The specific activity of RuBPCase appeared at a maximum of about $0.14 \mathrm{U}$ (mg protein) $)^{-1}$ at $D=0 \cdot 15 \mathrm{~h}^{-1}$. With increasing dilution rate the specific activity decreased almost continuously to $0.04 \mathrm{U}$ (mg protein) $)^{-1}$ at $D=0.4 \mathrm{~h}^{-1}$ (Fig. $1 c$ ).

\section{DISCUSSION}

The addition of $\mathrm{H}_{2}$ to $A$. eutrophus growing under carbon limitation in a succinate-limited chemostat resulted in mixotrophic growth. The yield increase with succinate plus $\mathrm{H}_{2}$ of $135 \%$ over the heterotrophic yield suggested that $95 \%$ of the carbon deriving from succinate was converted to cell carbon under optimal growth conditions. This evidence was supported by the data of total carbon analysis from cells grown under both conditions. Such an enormous yield increase has not been found for the mixotrophic capacities of other chemolithotrophic bacteria grown either in batch or chemostat culture. In batch culture the carbon monoxide oxidizing bacterium Pseudomonas carboxydoflava increased the yield by $7 \%$ and $35 \%$ growing on pyruvate plus $\mathrm{CO}$ or $\mathrm{H}_{2}$, respectively.

Thiobacillus A2 growing in an acetate-limited chemostat plus thiosulphate as additional energy source increased the yield by $55 \%$ compared to growth on acetate alone and about $76 \%$ of 
the acetate carbon was assimilated (Gottschal \& Kuenen, 1980). When Thiobacillus A2 grew on a substrate mixture of glucose plus thiosulphate, assimilation of glucose was increased at the expense of the energy derived from thiosulphate oxidation (Smith et al., 1980). The data on mixotrophic yields communicated for other thiobacilli or hydrogen bacteria cannot be compared, since growth was either energy-limited (Leefeldt \& Matin, 1980) or $\mathrm{CO}_{2}$ was included as an additional carbon source (Stukus \& DeCicco, 1970; Rittenberg, 1969). Convincing evidence has been obtained that in Thiobacillus A2 autotrophic $\mathrm{CO}_{2}$ fixation is not involved in mixotrophy, as evident from enzymic data of Smith et al. (1980) and Gottschal \& Kuenen (1980). In $P$. carboxydoflava, mixotrophic growth on pyruvate or glucose plus $\mathrm{CO}$ does not require $\mathrm{CO}_{2}$ fixation (Kiessling \& Meyer, 1982), as has also been reported for the hydrogen bacterium Aquaspirillum autotrophicum in a pyruvate-limited chemostat plus $\mathrm{H}_{2}$ (Fasnacht \& Aragno, 1982). In contrast, mixotrophic growth of $A$. eutrophus requires both $\mathrm{H}_{2}$ oxidation and autotrophic $\mathrm{CO}_{2}$ fixation. This was evident from physiological and biochemical studies with mutants defective either in chemolithotrophic or autotrophic metabolism. Mutants unable to oxidize $\mathrm{H}_{2}$ did not grow mixotrophically. However, the soluble hydrogenase was distinctly more effective than the particulate enzyme in contributing to mixotrophic growth, as shown by the higher transitional growth rate of the Hop ${ }^{-}$strain HF08 over the $\mathrm{Hos}^{-}$strain HF14. These data are in agreement with the previous findings of Schlesier \& Friedrich (1981).

The mutant $\mathrm{HF} 17$, unable to fix $\mathrm{CO}_{2}$ autotrophically but not impaired in $\mathrm{H}_{2}$ oxidation, did not increase the cellular yield significantly under mixotrophic growth conditions with succinate. A mixotrophic yield increase excluding autotrophic $\mathrm{CO}_{2}$ fixation can either derive from an altered metabolism of the heterotrophic substrate which avoids the catabolism to generate reductant for respiration or from heterotrophic $\mathrm{CO}_{2}$ fixation. For our studies we chose succinate, since the metabolism of this substrate does not allow a heterotrophic $\mathrm{CO}_{2}$ fixation for anaplerotic reactions or glucogenesis. These examples show that $A$. eutrophus is unable to alter the metabolism of heterotrophic substrate, when an additional energy source such as $\mathrm{H}_{2}$ is used.

The key enzymes of autotrophic metabolism are highly derepressed under succinate-limited growth (Friedrich, 1982). The addition of $\mathrm{H}_{2}$, however, decreased the high level of the soluble hydrogenase dramatically, due to inactivation as described previously. The particulate enzyme is not subject to inactivation in vivo or in vitro (Schlesier \& Friedrich, 1981) and consequently remained constant. The decrease in activity of the soluble enzyme, however, did not affect the mixotrophic yield.

The enormous increase of RuBPCase activity indicated that the cells were starved of carbon, since the key enzymes of autotrophic $\mathrm{CO}_{2}$ fixation are derepressed under this condition (Im \& Friedrich, 1983). Very probably this high enzyme level is necessary for the cell to refix effectively the $\mathrm{CO}_{2}$ generated from succinate catabolism. This is also evident from the growth rate dependent mixotrophic capacity of $A$. eutrophus. The contribution of the autotrophic metabolism to the increase in cellular yield and productivity is decreased above the maximum autotrophic growth rate of $0.21 \mathrm{~h}^{-1}$, where especially the activity of RuBPCase decreased significantly. Since $\mathrm{CO}_{2}$ is formed at a rate equivalent to the cellular productivity, the restriction in mixotrophic capacity is linked to the rate of synthesis or function of the key enzymes of autotrophic metabolism at faster growth rates.

We are grateful to Professor G. Whitesides for the generous gift of RuBP, to Dr E. Schmidt for his help in total carbon analysis and to A. Quentmeier for his excellent assistance during part of this work. We thank the Deutsche Forschungsgemeinschaft for financial support.

\section{REFERENCES}

Bowien, B. \& SChlegel, H. G. (1981). Physiology and biochemistry of aerobic hydrogen-oxidizing bacteria. Annual Review of Microbiology 35, 405-452.

FASNACHT, M. \& ARAgNo, M. (1982). Mixotrophy and lithoheterotrophy by Aquaspirillum autotrophicum. Experientia 38, 1377.
FRIEDRICH, C. G. (1982). Derepression of hydrogenase during limitation of electron donors and derepression of ribulosebisphosphate carboxylase during carbon-limitation of Alcaligenes eutrophus. Journal of Bacteriology 149, 203-210.

Friedrich, C. G. \& Friedrich, B. (1983). Regulation 
of hydrogenase formation is temperature sensitive and plasmid-coded in Alcaligenes eutrophus. Journal of Bacteriology 153, 176-181.

Friedrich, C. G., Bowien, B. \& FrIEdrich, B. (1979). Formate and oxalate metabolism in Alcaligenes eutrophus. Journal of General Microbiology 115, 185192.

Friedrich, C. G., Friedrich, B. \& Bowien, B. (1981). Formation of enzymes of autotrophic metabolism during heterotrophic growth of Alcaligenes eutrophus. Journal of General Microbiology 122, 69-78.

Friedrich, C. G., SCHNEIDER, K. \& FrIEDRICH, B. (1982). Nickel in the catalytically active hydrogenase of Alcaligenes eutrophus. Journal of Bacteriology 152 , 42-48.

Gottschal, J. C. \& Kuenen, J. G. (1980). Mixotrophic growth of Thiobacillus A2 on acetate and thiosulfate as growth limiting substrates in the chemostat. Archives of Microbiology 126, 33-42.

IM, D.-S. \& FRIEDRICH, C. G. (1983). Fluoride, hydrogen, and formate activate ribulosebisphosphate carboxylase formation in Alcaligenes eutrophus. Journal of Bacteriology 154, 803-808.

Kiessling, M. \& MeYer, O. (1982). Profitable oxidation of carbon monoxide or hydrogen during heterotrophic growth of Pseudomonas carboxydoflava. FEMS Microbiology Letters 13, 333-338.

LeAdbeater, L., Siebert, K., SChobert, P. \& Bowien, B. (1982). Relationship between activities and protein levels of ribulosebiophosphate carboxylase and phosphoribulokinase in Alcaligenes eutrophus. FEMS Microbiology Letters 14, 263-266.
LeEFeldT, R. H. \& Matin, A. (1980). Growth and physiology of Thiobacillus novellus under nutrientlimited mixotrophic conditions. Journal of Bacteriology 142, 645-650.

Matin, A. (1978). Organic nutrition of chemolithotrophic bacteria. Annual Review of Microbiology 32, 433-468.

RITTEnBERG, S. C. (1969). The roles of exogenous organic matter in the physiology of chemolithotrophic bacteria. Advances in Microbial Physiology 3, 159-196.

RitTENBERG, S. C. \& GoOdman, N. S. (1969). Mixotrophic growth of Hydrogenomonas eutropha. Journal of Bacteriology 98, 617-622.

SCHLESIER, M. \& FRIEDRICH, B. (1981). In vivo inactivation of soluble hydrogenase of Alcaligenes eutrophus. Archives of Microbiology 129, 150-153.

Smith, A. L., Kelly, D. P. \& WoOD, A. P. (1980). Metabolism of Thiobacillus A2 grown under autotrophic, mixotrophic and heterotrophic conditions in chemostat culture. Journal of General Microbiology 121, 127-138.

SteinmülleR, A. \& Bock, E. (1976). Growth of Nitrobacter in the presence of organic matter. I. Mixotrophic growth. Archives of Microbiology 108, 299-304.

Stukus, P. E. \& DeCicco, B. T. (1970). Autotrophic and heterotrophic metabolism of Hydrogenomonas: regulation of autotrophic growth by organic substrates. Journal of Bacteriology 101, 339-345. 